Relations industrielles

Industrial Relations

\title{
Gordon L. Clark, Unions and Communities Under Siege: American Communities and the Crisis of Organized Labor
}

\section{Martin J. Morand}

Volume 46, numéro 2, 1991

URI : https://id.erudit.org/iderudit/050685ar

DOI : https://doi.org/10.7202/050685ar

Aller au sommaire du numéro

Éditeur(s)

Département des relations industrielles de l'Université Laval

ISSN

0034-379X (imprimé)

1703-8138 (numérique)

Découvrir la revue

Citer ce compte rendu

Morand, M. J. (1991). Compte rendu de [Gordon L. Clark, Unions and

Communities Under Siege: American Communities and the Crisis of Organized Labor]. Relations industrielles / Industrial Relations, 46(2), 484-487.

https://doi.org/10.7202/050685ar

Tous droits réservés @ C Département des relations industrielles de l'Université Laval, 1991
Ce document est protégé par la loi sur le droit d'auteur. L’utilisation des services d'Érudit (y compris la reproduction) est assujettie à sa politique d'utilisation que vous pouvez consulter en ligne.

https://apropos.erudit.org/fr/usagers/politique-dutilisation/ 
cette classification pour deux raisons. D'abord, la fonction «conseil, recherche et planification» ne constitue pas un sous-champ des relations industrielles au même titre que les relations du travail et la gestion des ressources humaines. Cette fonction est le propre de toute discipline ayant une application pratique comme le droit, le service social, la psychologie, etc. D'ailleurs, la fonction «conseil, recherche et planification» s'applique autant au domaine des relations du travail qu'à celui de la gestion des ressources humaines; elle ne peut donc pas être considérée un domaine en soi. Ensuite, elle ne correspond pas du tout aux phénomènes qui sont décrits dans la quatrième partie du volume, à savoir: la discrimination au travail, le marché du travail, et les normes minimales. Ces phénomènes sont du ressort des politiques publiques en matière de travail et il aurait été beaucoup plus simple d'utiliser ce terme pour désigner cette dernière partie. Peut-être le coordonnateur s'est-il senti obligé d'utiliser une expression à consonnance «pragmatique» étant donné la portée souhaitée pour l'ouvrage et les caractéristiques du maître d'oeuvre, c'est-à-dire, la corporation professionnelle? Il n'en reste pas moins que le choix du terme est très malheureux.

Malgré cette dernière critique et le fait que certains textes soient un peu plus faibles que d'autres, Vingt-cinq ans de pratique en relations industrielles au Québec demeure un excellent ouvrage susceptible d'être utile autant aux praticien-ne-s qu'aux étudiant-e-s qui veulent se familiariser avec le champ d'étude des relations industrielles.

Jean BoIvin

Université Laval

Unions and Communities Under Siege: American Communities and the Crisis of Organized

Labor, by Gordon L. ClARK, England, Cambridge University Press, 1989, 309 p., ISBN 0-521-36516-3.

Gordon Clark echoes Tip O'Neil's "All politics is local politics" with his thesis that it is "in terms of the local context of labor-management relations" that the "current crisis of organized labor ought to be considered." While there is a large and growing literature of community-based studies of unions, workers and labor relations, these are primarily the work of historians. It is as a Professor of Geography that Clark adds a spatial dimension to the analysis expressed in the book's title, Unions and Communities Under Siege: American Communities and the Crisis of Organized Labor. Published in 1989 as part of Cambridge University Press' series on Human Geography, the dedication to his grandfather, "a railway worker and unionist of another time and place" indicates the author's sympathies.

Clark suggests that workers and unions have ultimately been more victim than beneficiary of the fact that, "[f]ostering decentralization has been an integral goal of federal labor law." Other commentators (e.g. George Brooks) have decried the existence of multi-local and multiemployer negotiations because they believe these large scale bargaining structures undermine the Wagner Act's guarantee to workers of "unions of their own choosing." Clark, on the other hand, says that the purpose of organizing is negotiating and effective negotiating requires a union structure matching the employers organization and power. He therefore concludes that worksite-based bargaining units fragment national (and international) union power. He contends:

There can be no doubt that the Wagner Act (1935) and the Taft-Hartley (1947) amendments made it relatively more difficult to organize labor in the United States than in other advanced countries. Unions have had to organize firms on a plant-by-plant basis, seeking representation rights for workers in different communities across the country. 
While they may be successful in some plants, they are required to organize all plants of a firm if they are to have a coordinated national agreement with a particular firm. Even in this case, if they are successful in organizing all plants of a firm, contract ratification often takes place at the local level. For reasons of local democracy, maintaining power of the local union in relation to the national union organization, the union movement has had to cope with a federal legal structure deliberately designed to fragment its national power.

Clark is not alone in noting the contradiction between autonomy and solidarity. Labor intellectual Solomon Barkin, based upon his experience within the Textile Workers Union in the 1930's, observed that organizing and bargaining gains in the decades following the Wagner Act had blinded U.S. union leaders to its fundamental flaw. Indeed, at no time, heyday or decline, have American labor leaders considered a fundamentally different (i.e. European) approach to recognition and negotiation systems. Rather they have vigorously promoted Wagner (successfully in Canada) as the sine qua non of free trade unionism.

Clark is looking backward from "another time and place". The time is the eighties when industrial restructuring, capital mobility and overt government hostility have led to takebacks, givebacks and cutbacks creating a "crisis of organized labor". The place is Pittsburgh where unions and the community were under siege as Clark studied and wrote while working at the Carnegie Mellon University Center for Labor Studies. He sees the same weakening effects which others have noted of Taft-Hartley with its encouragement of localism (e.g. state right-towork options) and Landrum Griffin with its weakening of inter-community labor solidarity (e.g. hot cargo bans). But he sees what few have noted, that the very law credited with the growth of the U.S. labor movement fostered the conflict between local democracy and effective national (or international) union power. (Fostered not created; William Sylvis, Terrence Powderly and Sam Gompers contended with it long before Wagner.)

Clark illustrates the way this conflict played itself out in a tale of two cities: Allentown, Pennsylvania where Mack Truck threatened, "...that the plant would close unless the Allentown UAW local agreed to significant cost reductions substantially equivalent to those that can be realized at the out-of-state location". The out-of-state location was Winnsboro, South Carolina, a non-union, low-wage site. The corporation (ironically and significantly the French government owned Renault Corporation) succeeded in getting the local union leadership to publicly attack the UAW International. It also effectively fostered auction block bidding between the two cities and two states as they competed to offer maximum subsidies and minimum labor costs. The UAW succeeded in moderating the cuts, protecting transfer rights of incumbent workers and ultimately winning union recognition in Winnsboro in spite of the local union, the local and state governments and the National Labor Relations Board. Clark notes that a European style of representation and negotiation more effectively inhibits such whip sawing.

A further fact: "... whereas corporations treat plants as mere components of larger plans, unions must treat locals as vital parts of the union as a whole". This fact of life is magnified in its impact because, "[t]he representation function is one vital force which sustains decentralization" as Clark illustrates in the local vs international conflict in the UAW's American Motors Corporation plants.

That the threat posed is a growing one is pointed out by Clark as he considers issues of "flexibility" and "cooperation" and the "concomitant dilemmas which union leaders face". "[T]hese partnerships typically involve radical reorganization of corporate production schemes on a plant-by-plant (local union-by-local union) basis". The implications are clear: "...cooperative restructuring proposals threaten the very future of unions as institutions". 
As Professor Bennett Harrison has noted, Clark offers an "historically grounded, institutionally complex theory of development driven by the interplay among three sets of fundamentally different kinds of hierarchical organizations whose operating principles were established in different historical moments: unions, governments and business". Nevertheless, I must add a caveat particularly for a Canadian audience. If location-specific representation is a problem for U.S. unionism, why is it not a greater difficulty in Canada which not only echoed the Wagner Act's approach but did so with many provincial permutations? If the absence of a nation-wide representational system impedes union unity and worker solidarity, how is it that union density is more than double in a nation where industrial relations is even more regionally and provincially differentiated than in the U.S.? If centralized unions and a united labor movement are essentials of effectiveness, how does Canadian labor manage with its multiple federations and sometimes apparently "open warfare" within the house(s) of labor? Why does statebased social legislation (e.g. Unemployment Compensation, Worker's Compensation) get leveraged lower by U.S. business lobbyists while provincial social and labor laws (e.g. healthcare, first contract arbitration) expand from province to province? Why is it obvious that a relocation to South Carolina is a cost-cutting (as well as union-avoiding) move but Canadian firms do not rush to Alberta or Nova Scotia even when union-weakening laws are adopted?

One U.S. "localism" may provide a partial answer: the South with its history of Constitutionally endorsed slavery and legally enforced segregation has created a divided working class. Whether in the failure of operation Dixie, the passage of right-to-work legislation or the threat to an industry standard wage posed by the southern differential, regionally rooted racism has always been the soft underbelly of U.S. labor's solidarity. If Clark is correct that "fostering decentralization" and thereby union weakness "has been an integral goal of federal labor law" perhaps the "southern veto" which operated even at the height of labor's political power in the mid 1930's is part of the reason for the Wagner Act's structural weakness. Canada overcame the Wagner Act's inherent weakness by enforcing it effectively and amending it so as to strengthen its purported purposes - encouraging collective bargaining. In contrast, in the U.S. meaningful enforcement is absent and, because of what Clark calls, "Republicans, Democrats and the Southern Veto", U.S. Wagner amendments (Taft-Hartley in particular) succeeded in transforming the National Labor Relations Act into an anti-labor law. (Some community oriented historian ought to investigate the influence of Southern Democrats in shaping the Wagner Act; they certainly successfully restricted the impact of other New Deal legislation on their communities.)

Clark quotes a Pennsylvania Congressman's 1935 warning:

The amendment (Wagner-Connery disputes bill) strikes a damaging blow against national unions which labor through its own efforts has created and degenerates into an extension of the Government-union idea, one union for each plant.

Clark's own conclusion brings this 1935 concern into the context of the global economy.

The underlying structure of labor law, which encouraged localization of labormanagement relations, has become a fundamental disadvantage for unions and communities in their bargaining with employers. Indeed, the very geography of the union movement has made it vulnerable to the global reach of corporate capitalism.

Clark's geocentric focus on the local community has important implications for nation states as we move toward Europe ' 92 and North American Free Trade systems. For how long 
will international capital and non-state corporations place workers and communities under siege until society faces "the exhaustion of an ideal and the perversion of the current structure of decentralized labor-management relations?"

Martin J. MORand

Indiana University of Pennsylvania

La conciliation dans les conflits du travail, par le BUREAU INTERNATIONAL DU TRAVAIL, Genève, 1988, 148 p., ISBN 92-2-201007-8.

Cette publication du Bureau international du Travail se veut un guide pratique pour encourager le règlement ordonné des conflits du travail. Ce document ne traite pas du cadre juridique de la conciliation mais plutôt du processus dans lequel cette conciliation doit s'effectuer dans la dynamique des attitudes, des comportements et des approches qui permettront aux personnes mandatées à jouer le rôle de conciliateur d'intervenir avec plus d'efficacité, et par conséquent avec plus de succès. Il s'agit donc d'un ouvrage purement didactique destiné à des fins pédagogiques et il est particulièrement plus adapté aux pays en développement qu'à ceux possédant un régime de rapports collectifs du travail structuré et dont les intervenants sont expérimentés en matière de conciliation ou mieux en matière de négociation collective assistée.

Le document est divisé en 12 chapitres que nous pouvons regroupés sous trois grands thèmes. Le premier nous permet de situer la notion de conciliation et présente succintement ce que devrait être un conciliateur ainsi que les principales habiletés et qualités que cette personne doit posséder pour avoir du succès.

Le second thème brosse les étapes de la préparation d'une conciliation. En fait il s'agit des informations que doit maîtriser le conciliateur ainsi qu'une description de la logistique inhérente à son travail soit: les contacts avec les parties, les réunions et leur conduite, les séquences de la conciliation.

Le troisième volet présente certaines techniques de conciliation mais uniquement liées aux habiletés personnelles du conciliateur. D'ailleurs l'ensemble du document laisse percevoir la très grande importance que les auteurs ont octroyé aux qualités personnelles de la personne qui fait de la conciliation.

Somme toute une publication du Bureau international du Travail qui permettra, non seulement au pays en développement, mais également aux novices de ce milieu de tous les pays industrialisés, de comprendre et de mieux saisir les différentes dimensions de la conciliation. Elle pourra aussi servir de point de repère et de rafraichissement au plan de l'éthique professionnelle à tous les spécialistes des rapports collectifs du travail.

Raynald Bourassa

InnovAccord

Les limites du partenariat. Les expériences sociales-démocrates de gestion économique en Suède, en Allemagne, en Autriche et en Norvège, par Louis GILL, Montréal, Boréal, 1989, 151 p., ISBN 2-89052-292-X.

Alors qu'on assiste au plan mondial à d'intenses mutations au sein des deux grandes économies dominantes (socialiste et capitaliste), le livre de Louis Gill tombe à point afin d'alimenter la réflexion sur la recherche de nouveaux types d'économies plus démocratiques, humaines et équilibrées. 